\title{
The Digitalization Features of the Russian Social Media Market Insurance Service
}

\author{
Submitted 08/08/19, 1st revision 11/09/19, 2nd revision 26/10/19, accepted 22/11/19 \\ I.P. Denisova ${ }^{1}$, K.N. Samoylova ${ }^{2}$, V.Y. Shirshov ${ }^{3}$, M.Z. Myzaev ${ }^{4}$
}

\begin{abstract}
:
Purpose: The article aims to identify the features of digital techniques introduction and functioning in the insurance industry and the social insurance system. The information techniques used allows to quickly and with the best results to process large amounts of data, thereby increasing the efficiency of all the spheres to reduce social and commercial risks.

Design/Methodology/Approach: In order to substantiate introducing the digital techniques expediency in the activity of the insurance system, it is necessary, first, to consider the advantages and disadvantages of information techniques use in the commercial and social insurance. Second, to describe the main digital programs, the implementation of which will increase the targeting and personalization of insurance services.

Findings: For the digital techniques introduction in the sphere of insurance relations it is necessary to form the wholly new structure of insurance assets that meet the priorities of the digital economy; to create the necessary conditions for the development and implementation of modern actuarial techniques; to create conditions for increasing incomes and the life standard of the population in order to stimulate demand for insurance services; to change the structure and quality of social services.

Practical implications: The results of the study can be implemented in the practice of social funds and insurance companies in order to improve the quality of insurance services.

Originality/value: The main contribution of this research is to transfer the processes and mechanisms for the global digital economy and global digital space formation to the social and insurance relations.
\end{abstract}

Keywords: Insurance, digitalization, insurance services, personalization of services.

JEL Code: C81,F65, G22, J26.

Paper type: Research article: Social Media Market.

\footnotetext{
${ }^{1}$ Professor of the Finance Department, Rostov State University of Economics, Rostov-onDon, Russian Federation, denis8663@Imail.ru

${ }^{2}$ Associate Professor of the Finance Department, Rostov State University of Economics, Rostov-on-Don, Russian Federation.

${ }^{3}$ Associate Professor of the Finance Department, Rostov State University of Economics, Rostov-on-Don, Russian Federation.

${ }^{4}$ Deputy Chief of the Department the Pension Fund of Russia in the Achkhoi-Martan district of the Chechen Republic.
} 


\section{Introduction}

The modern model of the modern state economic development is characterized by the institutional changes in various spheres of the economy. In most cases, these changes are associated with the ongoing processes of improving the spheres and links of the modern financial and economic sphere in the direction of the in-depth digitalization. Over the past 5-6 years, the trend of the economy digitalization captures an increasing number of countries and inevitably gains high rates in them. Russia is not an exception. The transition to digital techniques is a phenomenon that cannot be avoided. It certainly affects human life and carries both trends for the development and problems of the implementation (Bezsmertnaya, 2018).

The new techniques application is aimed at improving the availability, efficiency and security of services, the development of intuitive services, reducing costs, improving the quality, speed and reliability of services. The basis of the digitalization in the insurance relations is actuarial modeling, depending on a number of factors: demographic, socio-economic, macroeconomic, pension factors. In Western countries, there are universal models (the PROST model of the World Bank and the model of the International Labour Organization). These models allow actuarial modeling of any pension systems, both wholly distributive and funded, and mixed systems, regardless of the specifics of the legislation of a particular state (Bowers et al., 2001; Cristea and Thalassinos, 2016).

In the last decade the digital economy has become a key factor in the social development and contributes to the information space formation, taking into account the needs of citizens and society in obtaining high-quality and reliable information. Techniques and new sources of data are fundamentally changing our economy and society, and promise to transform the social insurance system. For example, the digitalization is changing the role of pension insurance from the pure risk protection to the risk prediction and prevention. The new opportunities offered by big data analytics and other digital techniques can allow to implement the principle of targeting and individualization in protection against social risks

\section{Method of Research}

As the methodological basis of the study, general scientific methods of the cognition were used: the observation, comparison, system logical-semantic analysis, synthesis of theoretical and practical material, which allowed to characterize the digital programs essence in the insurance industry and the system of insurance relations, to show their features and prospects of the development in Russia, to justify and develop practical recommendations for the introduction of information techniques in the modern insurance system of Russia (Polyakova et al., 2019).

The theoretical basis for the research are the works of domestic authors T.F. Romanova, E.P. Bezsmertnaya, I.P. Denisova, K.N. Samoilova (Romanov et al., 
2018; Malakhova and Samoylova, 2019). Significant scientific basis for the research in the field of problems and prospects of insurance relations are the studies of foreign authors such as Bowers N., Gerber H., Jones D., Nesbitt S., Hickman J. (2001) and others.

\section{Research Results}

On July 28, 2017, the government of the Russian Federation approved the program "Digital economy of the Russian Federation". The Program is aimed at creating conditions for the development of the knowledge society in the Russian Federation, improving the welfare and life standard of citizens of our country by increasing the availability and quality of goods and services produced in the digital economy using modern digital techniques, increasing awareness and digital literacy, improving the availability and quality of public services for citizens, as well as security both within the country, and beyond (Bowers et al., 2001).

The creation of a stable foundation for the further digitalization of the modern financial market of Russia, as well as for the formation of the necessary conditions of the development and implementation of modern financial techniques, is the most important activity of the Bank of Russia. The introduction of modern digital techniques makes it possible to develop the competition in the financial market, which inevitably increases the availability, quality and range of financial services and significantly reduces the costs of financial market participants. The protection of financial institutions and their clients from potential cyber threats is the necessary condition for the promotion of the digitalization in the modern Russian financial market. The Bank of Russia is developing special standards in the information security, the use of which will contribute to the growth of financial market participants confidence to modern innovative techniques.

Currently, in Russia, most issues of information and telecommunications are considered to be settled. However, there are barriers to the new institutions of the digital economy formation. Modern Russian society still faces the problem of accessibility of the Internet. Thus, in many sparsely populated areas there is no Internet connection, which partly explains the low level of the population literacy in the use of financial services through the digital platform.

The international digital economy and society index (I-DESI) provides an overall evaluation of five areas: connectivity, human capital and digital skills, citizens' use of the Internet, and the digital techniques integration into public services. According to the study, Russia lags behind the leading European countries in the digital economy development, but is ahead of China, Brazil, Mexico and Turkey. The government of the Russian Federation has planned to achieve by 2024 the following indicators in the information infrastructure: 
1. the share of households with broadband Internet access (100 Mbit/s) in the total number of households is 97 per cent;

2. in all the major cities (1 million people or more) there is sustainable coverage of $5 \mathrm{G}$ and above;

3. the share of the domestic network traffic of the Russian segment of the Internet network routed through foreign servers is 5 percent. (Denisova and Linnik, 2010).

Citizens of the Russian Federation recognize the need to use digital techniques for a number of reasons:

$>$ the ease and convenience to obtain the information and remote communication;

$>$ the ability to use free digital products;

$>$ easy access to services that were previously unavailable or that were timeconsuming to obtain;

$>$ new forms of leisure (Denisova, 2016).

Despite serious difficulties, the financial sector of the Russian Federation is one of the most dynamically automated sectors of the economy. The digital techniques use to provide financial services encourages innovation in the financial sector. According to the research results the most promising financial techniques are:

$>$ BigData and data analysis;

$>$ Mobile techniques;

$>$ Artificial intelligence;

$>$ Robotization;

$>$ Biometrics;

$>$ Distributed registries;

Cloud techniques.

The availability of financial services is increasing due to the emergence of new models of their provision. Thus getting the service "in one click" is becoming more and more popular in the financial market. The key factor of this model is efficiency, convenience and speed. SupTech (supervision technology) involves the innovative techniques use by the regulators to improve the efficiency of the processes of the regulation and supervision of financial market participants (Rupeika-Apoga et al., 2019). Tools such as BigData, SupTech, RegTech can allow the financial regulators to simplify the process of working with documentation, translate all data into digital format, improve the information quality and thus improve the financial sector of the economy (Medetov, 2016). In order to create a favorable environment for the digitalization of the financial market digital profile platforms are being created:

1. The platform for the remote identification will increase the financial services availability for consumers, including people with disabilities, the elderly and the disabled population; 
The fast payments platform is aimed at creating an open financial market, simplifying online transfers with transparent tariffs, providing convenient and innovative services for financial services consumers;

2. The financial transaction registration platform will provide the registration and maintenance of a single register of transactions in the financial market, etc.;

3. Cloud services platform.

Cloud technologies provide huge opportunities for insurance companies to use new technologies and compete with larger market players. However, this carries a risk of information security. The use of digital technologies in insurance can be considered as a factor that provides a breakthrough in improving the quality of insurance services. It has the following undoubted advantages: the costs reduction for the promotion of insurance products and settlement of losses; saving time of consumers on registration of insurance transactions; increase of speed of settlement of losses; increase of transparency at registration of insurance cases and their consequences; simplification of cash flow and its cost due to carrying out electronic operations; possibility of obtaining by insurers of more detailed information on behavior of insured that will positively affect specification of insurance tariffs; the opportunities to promote insurance products through social networks; the creation and promotion of complex products that combine insurance, pension, banking and investment products, etc.

The most important problems associated with the digitalization of the Russian insurance market and requiring early solutions are the issues of legal regulation of all the digitalization processes, including those that are caused by the features of the current state of the Russian insurance market and the specifics of the insurance service itself. A new approach to the protection against risks or to reduce them is the transition from the risk insurance to the prevention of the insured event, which became possible only on the digitalization basis.

According to the Bank of Russia, in 2018, sales of insurance products via the Internet for the year doubled and amounted to $5 \%$ of the total insurance premiums or about 74 billion rubles. The Main reason for this growth is the active development of electronic CTP. Thus, in 2018, the share of CTP premiums received through Internet channels more than doubled and reached 30.6\% (Medetov, 2016). The Internet sales development in OSAGO not only increases the insurance services availability, but also leads to a reduction in the costs of the insurer to conclude insurance contracts by saving on Agency fees, which makes any insurance project more profitable.

Despite the obvious advantages of the electronic insurance implementation both for insurers and policyholders, today there is some economic and legal vacuum regarding the legitimacy of electronic insurance contracts from the standpoint of the fundamental insurance legal acts. For example, the civil legislation contains a requirement for the mandatory written registration of insurance contracts and the seals and signatures in the insurance documents. It is possible to solve this 
contradiction by introducing the possibility of electronic signature of insurance documents. In this case, the digital techniques introduction in insurance at various levels is beneficial to both insurers and policyholders. Collecting the information about the policyholder and the digitalization of data on insurance cases in a common database make it possible to form a complete picture of each case, apply insurance rates individually to each person and make predictions about the likely consequences of insurance risks.

The degree of insurance fraud should also be reduced through the electronic poles introduction everywhere. As the accounting system incorporated in it will not allow to conclude the contract retroactively. This method allowed to solve the problem with the main method of fraud in Russia and the near abroad. And also the problem of double poles is solved when one is valid and the other is not. Currently, the digitization of existing data of insurance companies and the introduction of new technologies, such as trackers or telemetry devices for the car serving to collect and process new data about the insured persons.

The advantages of digital techniques in the field of insurance, as well as for insurance companies, as well as the insured person, the main of which is the optimization of the price of the insurance policy. Measures to work with the population in the field of financial literacy and the introduction of digital technologies are considered a necessary factor for the development of the financial economy in the Russian Federation. The global insurance market is estimated at five trillion dollars. The market of innovative techniques in insurance is only gaining momentum. Investment in innovative techniques in insurance is about three billion per year.

The insurance market can develop only in the condition of the high quality of insurance services and culture of insurance relations that in the modern digital world is impossible without the appropriate ways of the insurance contracts conclusion and further settlement of insurance events (CBR, 2019; Romanov et al., 2018).

The Bank of Russia, as a regulator in the insurance market, fully promotes initiatives to introduce digital techniques in the daily lives of domestic insurers as quickly as possible. The consequence of these initiatives are new approaches to the implementation of insurance marketing and accounting in the insurance organization, which in turn leads to the withdrawal from the market of players (insurance companies), unsatisfactory to the new high requirements of the regulator.

Thus, on 01.01.2019, only 196 insurance companies were registered in the state register (Figure 2). Over the past five years, the number of Russian insurance companies has decreased by almost 50\% from 391 in 2014 to 196 in 2018. 
Figure 2. Dynamics of the insurance companies number in 2014-2018.

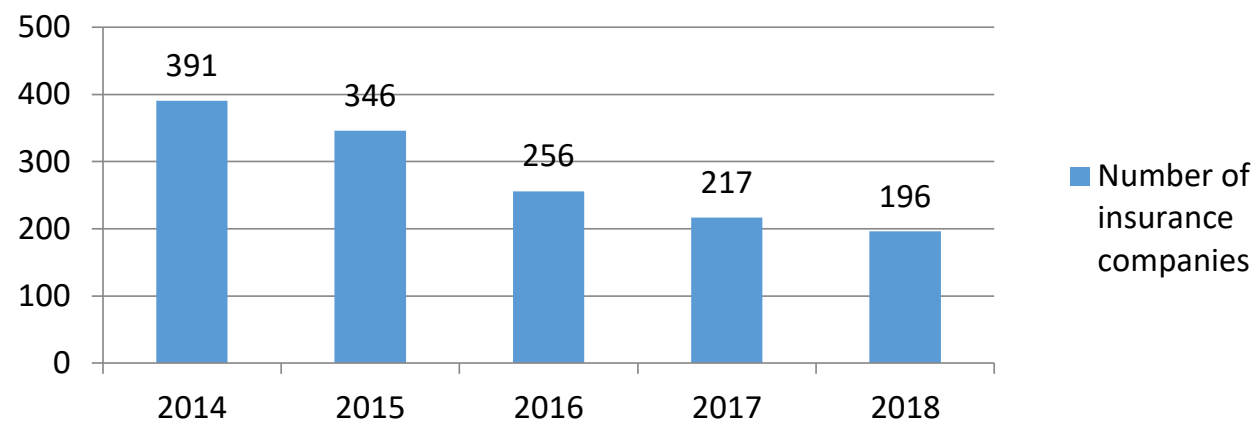

The tendency to reduce the number of insurers on the modern insurance market is determined not only by the controller to control the reality of the assets of insurance companies, but also a complex of measures, directed on the increase of the insurance business digitalization level. If such rates continue, by the end of 2019 there will be less than a hundred insurance companies in Russia. In 2018, the total fees of insurers increased by $15.7 \%$ and amounted to 1,479 billion rubles, the volume of insurance payments also increased by $2.5 \%$, and amounted to 522.4 billion rubles (Figure 3 ).

Figure 3. The dynamics of insurance premiums in 2017-2018, billion rubles

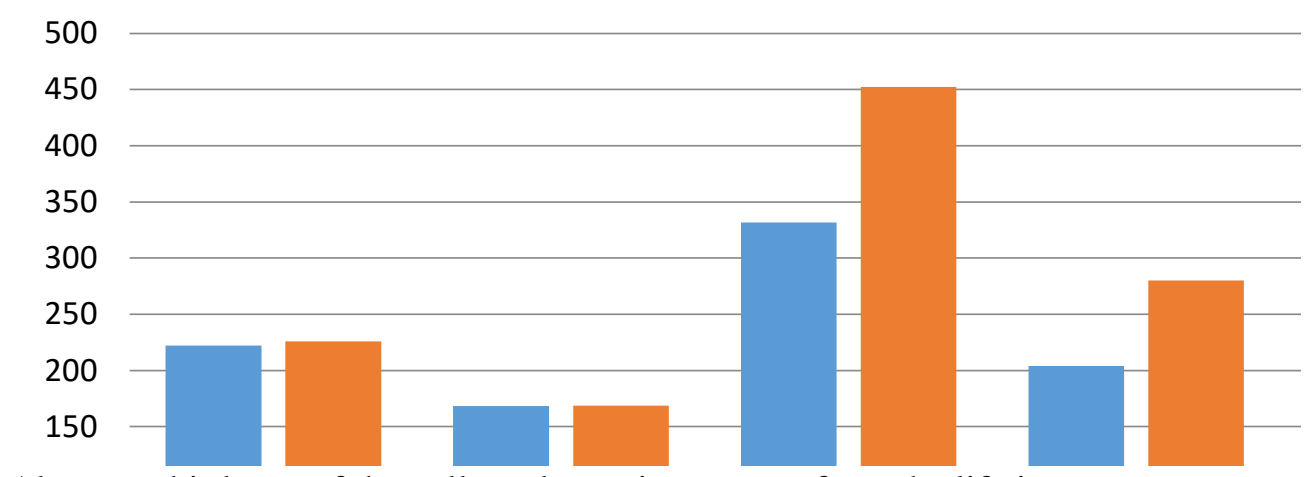

Almost a third part of the collected premiums came from the life insurance segment, which grew by $36.5 \%$. Insurance payments for life insurance also increased by $83.8 \%$, to 67 billion rubles, which is primarily due to the expiration of previously concluded medium-term contracts. Every year the intensity of the digital tools use by the financial sector's in its business projects increases, and IT becomes a leading direction of the strategic development. In addition, the largest insurance companies identify the digitalization as one of the key trends and actively invest in this area.

As can be seen from the data presented in Table 1, the share of Internet sales in the domestic insurance market is steadily growing. To date, a great prospect for insurers in the development of the segment of mass types of insurance with the help of modern digital technologies is obvious. It is especially important to develop this 
direction in the implementation of the most popular types of insurance, such as CTP insurance (compulsory insurance of civil liability of vehicle owners), CASCO (voluntary insurance of vehicles), VZR (insurance of medical expenses, citizens traveling abroad). In addition to the above types of insurance, all the social insurance companies have the high heuristic potential in relation to digitalization use: additional pension social insurance, which take place in the activity of the state and non-state pension insurance.

Table 1. The dynamics of Internet insurance in Russia (2017-2018) (CBR, 2019).

\begin{tabular}{|l|c|c|c|c|}
\hline \multicolumn{1}{|c|}{ Indicator } & Units & $\mathbf{2 0 1 7}$ & $\mathbf{2 0 1 8}$ & Change \% \\
\hline $\begin{array}{l}\text { Insurance premiums under } \\
\text { insurance contracts concluded via } \\
\text { the Internet, including: }\end{array}$ & $\begin{array}{l}\text { million } \\
\text { rubles }\end{array}$ & 32021,0 & 74651,2 & 133,1 \\
\hline $\begin{array}{l}\text { Insurance premiums under CTP } \\
\text { contracts concluded via the } \\
\text { Internet }\end{array}$ & $\begin{array}{l}\text { million } \\
\text { rubles. }\end{array}$ & 28467,1 & 69233,1 & 143,2 \\
\hline $\begin{array}{l}\text { The share of insurance premiums } \\
\text { under insurance contracts } \\
\text { concluded via the Internet in the } \\
\text { total amount of insurance } \\
\text { premiums }\end{array}$ & $\%$ & 2,5 & 5,0 & 2,5 \\
\hline
\end{tabular}

\section{Conclusions and Recommendations}

The development of Internet sales in the insurance industry and social insurance not only increases the availability of insurance services, but also leads to reducing the costs of the insurer to conclude insurance contracts by saving on agency fees, which makes any insurance project more profitable (Samoylova, 2018). Despite the obvious advantages in the implementation of electronic insurance for both insurers and policyholders, today there is some economic and legal vacuum regarding the legitimacy of the electronic insurance contracts from the standpoint of fundamental insurance legal acts. For example, the civil legislation contains a requirement for mandatory written registration of insurance contracts and seals and signatures in insurance documents. It is possible to solve this contradiction by introducing the electronic signature of insurance documents.

In this case, the introduction of digital techniques in the insurance at various levels is beneficial to both insurers and policyholders. The collection of the information about the insured and the digitization of data on insurance cases in a common database make it possible to form a complete picture of each case, apply insurance rates individually to each and make predictions about the likely consequences of insurance risks. The digital platform of social insurance funds of Russia accumulates digital social services. On the one hand, it should reduce the transaction costs of the department, and on the other - to ensure the active development of the domestic economy digitalization. 


\section{References:}

Bezsmertnaya, E.R. 2018. The Digitalization of the Financial Sector of the Economy: who will receive digital dividends? Economy. Tallage, Right, 2(11), 75-83.

Bowers, N., Gerber, H., Jones, D., Nesbitt, S., Hickman, J. 2001. Actuarial mathematics. Moscow, Yanus-K.

CBR. 2019. Official website of the Bank of Russia. Available online: www.cbr.ru.

Cristea, M., Thalassinos, I.E. 2016. Private Pension Plans: An Important Component of the Financial Market. International Journal of Economics and Business Administration, 4(1), 110-115.

Denisova, I.P. 2016. Modeling the Cost of Social Services. Proceedings of the X International Conference on Economics, 71-76.

Denisova, I.P., Linnik,V. 2010. Actuarial Modeling of the Social Services Cost. Issues of Economics and Law, 0.

Malakhova, V.V., Samoilova, K.N. The the Financial Sector Digitalization in the Russian Federation. In Materials of XI MNPK. Government and business. The ecosystem of the digital economy, Saint-Petersburg, 131-134, available online: http://tofuture.ru./konferencii /gosudarstvo-i-biznes/arhiv.

Medetov, A.A. 2016. The Term BigData and Ways of its Application. Young scientist, 11, 207-210.

Polyakova, A.G., Loginov, M.P., Serebrennikova, A.I., Thalassinos, E.I. 2019. Design of a socio-economic processes monitoring system based on network analysis and big data. International Journal of Economics and Business Administration, 7(1), 130-139.

Romanov, D.G., Otrishko, M.O., Romanova, T.F., Samoylova, K.N., Andreeva, O.V. 2018. The Role of Clusters in the Financial Innovations Creation in the Sphere of Social Insurance. Espacios.

Rupeika-Apoga, R., Romanova, I., Bule, L., Thalassinos, E.Y. 2019. The Impact of Population Ageing and Social Stratification: The Case of Latvia. International Journal of Economics and Business Administration, 7(1), 49-63.

Samoilova, K.N. 2018. Trends in the Development of the Regional Insurance Market in Modern Conditions. Economics and Entrepreneurship, 8, 345-349.

SP. 2017. The State Program "Digital Economy of the Russian Federation". Available online: http://static.government.ru. 